\title{
Family eJournal as an Online Relationship Enhancement Tool: A Preliminary Investigation
}

\author{
Trey Asbury ${ }^{1 *}$ and Kevin R. Strauss ${ }^{2}$ \\ ${ }^{1}$ Department of Psychology, Texas Woman's University, Texas, United States \\ ${ }^{2}$ Founder \& President of Family eJournal, Columbia, Maryland, United States
}

Received: February 19, 2014; Accepted: April 07, 2014; Published: April 09, 2014

*Corresponding author: Trey Asbury, Department of Psychology, Texas Woman's University, Texas, United States, E-mail: EAsbury@mail.twu.edu

\begin{abstract}
The use of online social networking sites (SNS) has become increasingly popular during the past decade. While motivation to use SNS varies, the current pilot study examines the usefulness of a specific SNS, Family eJournal, as a therapeutic tool. Specifically, use of this online Q \& A website was evaluated as a mechanism for improving connections with family and friends. Qualitative responses were overwhelmingly favorable from a sample of college students during a 14-week trial. While a more in- depth quantitative analysis is warranted, current results suggest SNS platforms such as Family eJournal may be a convenient tool for enhancing relationship quality and overall well-being.
\end{abstract}

Keywords: Social networking sites; Life satisfaction; Well-being; Family eJournal

\section{Introduction}

There is a growing body of empirical work that deviates from pathology and dysfunction and focuses on a strengths-based approach. A considerable amount of research has recently begun to focus on the well-being and happiness derived from the use of online social networking sites (SNS) [1,2]. As many college students travel far from home, the use of SNS is an attractive platform for communication as it makes friends and family more accessible regardless of time and location. The online environment may also inhibit self-censorship by means of a platform that is less threatening than face-to-face interactions [3].

Kim and Lee [4] examined the effects of self-presentation on personal well-being in a sample of college student Facebook users. Results supported the notion that self-presentation to Facebook friends contributed to the user's well-being. However, perceived social support and number of Facebook friends were negatively related. In essence, a larger number of friends may result in shallow relationships that would not be predictive of social support and personal well-being [4]. In a similar study, Asbury and Hall [5] found that highly engaged SNS participation (not number of friends) was a predictor for personal well-being.

Ellison, Steinfield and Lampe [6] suggest that SNS are commonly used for the maintenance of social relationships that may otherwise be defined by a weak personal connection. However, SNS platforms like Facebook may not directly address meaningful personal connections. Researchers are just beginning to examine the potential benefits of SNS as therapeutic group platforms. Lemma and Fonagy [7] found that the asynchronous communication between therapist and client are attractive to those who value the self-paced nature of the interactions.

The current pilot study attempts to evaluate the SNS platform Family eJournal (FEJ), which is designed to enhance relationship quality between family and close friends. Family eJournal is a web-based activity that utilizes private, asynchronous dialogue wherein users are prompted with sets of four questions and when answered, only members of your "family" are able to access and read. It was founded and designed by biomedical engineer Kevin Strauss, M.E. who has nearly 10 years of experience in positive behavior modification interventions. While the site does not provide psychotherapy, questions are designed to promote reflection and discussion between self-selected groups. Family eJournal is a commercial available website that is free for individual families to join and offers a fee-based program for organizations interested in offering a mental and emotional wellness program to its members.

FEJ questions are designed to help users share their thoughts and feelings about everyday life events. FEJ asks nonconfrontational and non-controversial questions and does not have an underlying agenda (e.g. religious, political, etc.). The goal is to remove pressure and level the field so each person is comfortable sharing opening and honestly. In doing so, family/ group members are able to learn about and better understand that person. Sample questions include:

- Describe how you feel today.

- What was your first thought or feeling when you awoke this morning?

- Describe a memorable experience from elementary school.

- How would you define a really good conversation?

The goals of the present study were to compare users of FEJ 
to non-users on measures of family cohesiveness and overall life satisfaction. It was predicted that FEJ users would report higher levels of overall life satisfaction compared to non-users. In addition, we predicted the FEJ users would report general satisfaction with the SNS platform at the end of the trial period.

\section{Method}

Psychology students at a Texas university were challenged to use FEJ to enhance relationships with family and/or friends $(\mathrm{N}=66)$. Two classes were recruited to participate. The control class $(n=30)$ did not use FEJ while the experimental students (FEJ group) were asked to recruit 3-5 members from their family or close social network. The FEJ students were also asked to use the website at least one time per week. The Life Satisfaction Questionnaire Diener [8] was administered to all participants preand-post timeline for FEJ usage. This scale includes 5 Likert scale items such as, "I am satisfied with my life" and "In most ways my life is close to my ideal" (Cronbach's Alpha $=0.88$ ). A qualitative user evaluation (please comment about your experience using Family eJournal) was also completed by FEJ users at the end of the program and students provided anonymous feedback.

\section{Results}

All students from the FEJ group registered and recruited at least three members of their social network. During the 14-week program, a total of 51 families and 199 family members accessed FEJ. Website usage data was collected using the host server and Google Analytics (GA). GA generates detailed statistics about a website's traffic and traffic sources and measures conversions. Family eJournal's host server data was used to determine specific behavior about the cohort's activity (e.g. number of families, number of family members, logins). FEJ data and Google Analytics confirm that they were able to successfully navigate FEJ and remained engaged 14 times longer than the average website visit [9]. An average of 30 users visited FEJ each day, 60\% of visitors were returning, $30 \%$ of the users used FEJ more than $1 \mathrm{x} /$ week and the average visit lasted $7 \mathrm{~m} 12 \mathrm{~s}$. The average number of eJournals completed was nine and the most completed by a user was 46.

The quantitative analysis revealed a high degree of life satisfaction at the study outset and no significant differences were reported on life satisfaction between groups. Post intervention, there was no statistically significant change in life satisfaction between control (pretest $\mathrm{M}=20.2, \mathrm{SD}=6.4$ ) and FEJ ( $M=25$, SD 5.4) groups. However, eighty-three percent of the FEJ group reported that FEJ helped improve their relationship connections. Only one of the 36 reviews was reported to be a negative experience (see Table 1).

\section{Discussion}

Unfortunately, the quantitative results did not measure FEJ's potential effectiveness. All users began the study with a high degree of life satisfaction and hence there was a limited opportunity (i.e. ceiling effect) to improve that metric. Also, using FEJ only once per week may be too infrequent to elicit change. A better measure of therapeutic efficacy might include a placebo group for added control and comparison to the FEJ group. Since the present study utilized two separate college courses, future designs might employ a crossover design to protect against potential course content confounds. A measure of overall

Table 1: Familyejournal Qualitative Reviews.

\begin{tabular}{|c|c|c|}
\hline Response & Review & Comment \\
\hline 1 & Positive & $\begin{array}{l}\text { It was interesting to learn about different thoughts of my family and friends. Some of the answers they gave to those questions; } \\
\text { I never knew that some felt that way. I think it creates an awareness of one's actions and opens the lines of communication } \\
\text { for those that have been remiss in doing so. Some of my friends and family members I talk to, but the cares of life sometimes } \\
\text { prevents us from speaking more regularly about the deeper things going on in our lives. I think some of my friends just wanted } \\
\text { to help me, so they did it and the answers may not have been succinct enough and may lead to misinterpretation on limited } \\
\text { information. }\end{array}$ \\
\hline 2 & Positive & $\begin{array}{l}\text { I really like the family eJournal it has brought me and husband together. I am able to read his discussions on things he normally } \\
\text { would not share. I think the layout of the family eJournal is pretty user friendlier also. }\end{array}$ \\
\hline 3 & Neutral & $\begin{array}{l}\text { Honestly, I lost one of my participants over the course of the semester and going to do the Journals just reminds me of our falling } \\
\text { out. That is obviously no fault of the program, just a personal issue. Otherwise, I feel like some of the questions could have been } \\
\text { better thought out to provoke conversation between my family members and me as some of them were a little trivial and were } \\
\text { too easy to answer without truly contemplating them. }\end{array}$ \\
\hline 4 & Negative & $\begin{array}{l}\text { I tried to use it with my family hoping we could communicate better and become closer but the more I asked the more they } \\
\text { refused. Unfortunately, the Family eJournal experience only solidified my family's lack of communication skill and desire to help } \\
\text { each other. It also made me realize that I do not have any friends who would be willing to help me when I needed it. }\end{array}$ \\
\hline 5 & Positive & It was a good experience to help people come together. It was just hard to make sure everyone logs on. \\
\hline 6 & Positive & $\begin{array}{l}\text { It was very interesting to view the thoughts and ideas of my family and friends while also putting simple things into perspective. } \\
\text { I thought it was very helpful in improving communication and opening dialogue with members of your close circle. }\end{array}$ \\
\hline
\end{tabular}




\begin{tabular}{|c|c|c|}
\hline 7 & Positive & $\begin{array}{l}\text { I enjoyed it, reading my little brothers responses and my fiancé's have me comfort and I learned new things I did not know } \\
\text { about them. My brother and I have had conversations but he is better at expressing himself on paper than in person. }\end{array}$ \\
\hline 8 & Positive & I really enjoyed it except my husband never really did his which made me really mad. \\
\hline 9 & Positive & $\begin{array}{l}\text { I love using the family eJournal and reading about how my friends are feeling. It's a way to just put everything down that } \\
\text { affecting us in the day. I feel better once theJournals are done because it can change my outlook. Some emotions can't be } \\
\text { expressed with words to everyone but theJournal gives up an open door. I remember reading my friend's eJournal and knew } \\
\text { she was having a horrible day. I didn't meant theJournal but I called her that day and we went out for lunch. It was a way to say } \\
\text { I understand and if all you need is a shoulder that I would be there. }\end{array}$ \\
\hline 10 & Positive & $\begin{array}{l}\text { It was ok. It was really difficult for me to get my family to participate. My mom did though which was really nice. She actually } \\
\text { seemed to enjoy it. I wish there was a way to get my family to want to communicate more. }\end{array}$ \\
\hline 11 & Positive & I really enjoy using Family eJournal it is fun to answer the questions every week. \\
\hline 12 & Positive & $\begin{array}{l}\text { It was useful, as I go back and read what my brother wrote during theJournal experience, I was able to learn more about him in } \\
\text { that time period than when we are in person. Before, I think it is true to say we didn't really have much of a conversation, but it } \\
\text { has greatly improved getting to know him more through Family eJournal. We are both shy, and introverted, so communicating } \\
\text { through online has improved our sibling bond. }\end{array}$ \\
\hline 13 & Positive & $\begin{array}{l}\text { Family eJournal has significantly helped my family and I understand how we truly feel about something, without having to feel } \\
\text { anxious or uncomfortable. The questionnaires helped us connect, even with the distance that lies between us. }\end{array}$ \\
\hline 14 & Positive & I love using Family ejournal. Not only me but my family members, who I choose to do it with, enjoy it as well! \\
\hline 15 & Neutral & It has been okay, but my family members I chose to do it with have not been very helpful in doing their part. \\
\hline 16 & Positive & $\begin{array}{l}\text { I really enjoyed using Family eJournal. I know my family enjoyed getting to hear about each other's days and I found that I } \\
\text { would fill out more of them all at once, just because I enjoyed the questions. It was a good thing for my family and I since we } \\
\text { don't get to see each other very often. }\end{array}$ \\
\hline 17 & Positive & Overall it is a great way to get your thoughts out for others to read and relate to. \\
\hline 18 & Positive & $\begin{array}{l}\text { I have a good experience with my Family eJournal. It really makes me think about my surroundings and the things I have done } \\
\text { lately. It is a good way to reflect on one self. }\end{array}$ \\
\hline 19 & Positive & $\begin{array}{l}\text { Some of the questions are almost too vague to really answer. Overall, I feel like I have had an overall positive experience with } \\
\text { the Family eJournal. I don't feel like the questions have sparked conversation between my family and me. The only time the } \\
\text { eJournal is brought up is to see how one another are responding or to ask what the question is really asking. }\end{array}$ \\
\hline 20 & Positive & $\begin{array}{l}\text { Family EJournal has been an interesting experience. Although it was interesting learning some of the answers from my family, } \\
\text { and be able to express random bits of information about myself, such as favorite book or plans for the current weekend, most } \\
\text { of the answers are things that I already discuss. }\end{array}$ \\
\hline 21 & Positive & $\begin{array}{l}\text { With my family in person. I think Family EJournal has both positive and negative qualities that mainly depend on the individual. } \\
\text { For someone who is distant from his or her family, this system is great to keep in touch and learn from, but from someone who } \\
\text { lives in close proximity, this is something that can come in between actual face-to-face conversations. One major benefit that I } \\
\text { noticed from this experience was discovering how supportive my family can be when helping me in a school assignment. }\end{array}$ \\
\hline 22 & Positive & I really enjoyed using Family eJournal. I was able to learn new things about my family members I didn't know before. \\
\hline 23 & Positive & $\begin{array}{l}\text { I really enjoyed using family eJournal but it was difficult to answer some of the questions at times. Reading my family members } \\
\text { responses was cool and helped me to understand their perspective just slightly more than before using the Family eJournal. }\end{array}$ \\
\hline 24 & Positive & $\begin{array}{l}\text { The experience has been very fun for me and my family. I believe the most fun has been the responses my teenage son has } \\
\text { provided throughout the semester. He is in his first semester of college and seems to be stuck in the sullen teenager phase right } \\
\text { now. His responses have been very entertaining to us and as the semester has progressed we are seeing a slight shift of him } \\
\text { beginning to move out of his sullen phase into a more phase with a more positive outlook. However, this has not been evident } \\
\text { in theJournal responses but most evident in the times we visit him at North Texas. }\end{array}$ \\
\hline 25 & Positive & $\begin{array}{l}\text { Actually, FEJ has been more beneficial than I had originally thought. My sister, boyfriend, and a close friend of mine all use it. It } \\
\text { is interesting to find out new things about them and how they view life. It makes you realize how little you actually know about } \\
\text { people and their day to day routine. }\end{array}$ \\
\hline 26 & Positive & $\begin{array}{l}\text { Using the Family eJournal is very interesting and it is fun to see all of the different responses that my friends and family have } \\
\text { about the same questions. }\end{array}$ \\
\hline 27 & Positive & $\begin{array}{l}\text { Using Family eJournal has been interesting, it has made me stop and think about things I generally may not put much thought } \\
\text { to. Also, it was fun seeing the responses of my family and chatting about it. }\end{array}$ \\
\hline 28 & Positive & $\begin{array}{l}\text { Some of the questions are hard to understand. I understand them differently than what my friends see them. But overall I enjoy } \\
\text { getting to see their views and opinions on different things. }\end{array}$ \\
\hline 29 & Neutral & It really did not affect the way I communicate with my family because we pretty much share everything already. \\
\hline 30 & Neutral & $\begin{array}{l}\text { My family and I have really not found it to be beneficial. I have not found it sparked conversation. To be honest, we talk } \\
\text { more about our family on Facebook than FeJ. Maybe if we were a family that had trouble communicating than we could need } \\
\text { conversation starters. Also, the survey is very vague in its definition of family. My immediate family, children and spouse, } \\
\text { and amazing; but I have no connection to my parents or extended family. As such, I answered the questions based upon my } \\
\text { immediate family. }\end{array}$ \\
\hline
\end{tabular}




\begin{tabular}{|c|c|c|}
\hline 31 & Positive & $\begin{array}{l}\text { I thought it was very interesting to see how other people thought about different aspects of their lives. The only thing is that } \\
\text { after a while people stopped answering the questions. I really enjoyed all the questions because it made me think and allowed } \\
\text { those near me to see a different side of me. }\end{array}$ \\
\hline 32 & Positive & $\begin{array}{l}\text { Over the course of the semester, I have grown to like theJournal entries. Though last weekend was the first time I have sat down } \\
\text { with my family and discussed some of our entries, being able to read them has shown me that no matter how much you think } \\
\text { you know someone in your family, you don't. After reading some of my family members entries I have been able to see certain } \\
\text { situations through their eyes. Seeing their side of things has really helped and opened up my eyes to "adult" life and that hard } \\
\text { work does pay off. }\end{array}$ \\
\hline 33 & Positive & $\begin{array}{l}\text { The family eJournal has been extremely helpful in strengthening communication in my family. I have learned so much about } \\
\text { my soon to be mother in law, nephews, and even a little about my fiancé. My sister and nephews are living in China, so it has } \\
\text { made us communicate more regularly which has been amazing, because often times I forget to Skype or call especially due to } \\
\text { time distance, and it has been amazing getting to read what they are experiencing. I have really enjoyed the family eJournal and } \\
\text { believe it has so much to offer. }\end{array}$ \\
\hline 34 & Positive & The reason I like eJournal is because it helped get close to my friends. \\
\hline 35 & Positive & $\begin{array}{l}\text { I liked the experience because I was able to learn more about my husband and close friends. Family eJournal asked questions I } \\
\text { would have not thought of asking. }\end{array}$ \\
\hline 36 & Neutral & Some days it's enjoyable to write in but other days it is a chore. \\
\hline
\end{tabular}

relationship satisfaction should also be utilized.

Despite the weaknesses noted, the qualitative evaluation, including the high return in visitors per day and long visit duration, suggest that FEJ offers something worthwhile to its users. In the future, we aim to recruit participants who may identify with high-risk behaviors, such as alcohol/drug use, eating disorders, anxiety, and depression. The overwhelming positive evaluations from users in our pilot study suggest that FEJ may benefit users who are in high need of social support and relationship enhancement. These factors are strong predictors of personal and academic success and critical to the mental health and well-being of college students.

\section{References}

1. Webster S, Danforth (2013) Social networking sites and the evaluation of applicants and students in applied training programs in psychology. Training and Education in Professional Psychology 7(3): 145-154.

2. Gowen K, Deschaine M, Gruttadara D, Markey D (2012) Young adults with mental health conditions and social networking websites: Seeking tools to build community. Public Rehabilitation Journal 35(3): 245-250.
3. Lee G (2011) Use of Social-Networking Sites and Subjective WellBeing: A Study in South Korea. Cyberpsychology Behavior \& Social Networking 14(3): 151-155.

4. Kim J, Roselyn Lee J (2011) The Facebook paths to happiness: Effects of the number of Facebook friends and self-presentation on subjective well-being. Cyberpsychology Behavior and Social Networking 14(6): 359-364.

5. Asbury T, Hall S (2013) Facebook as a mechanism for social support and mental health wellness. Psi Chi Journal of Psychological Research 18: 124-129.

6. Ellison N, Steinfield C, Lampe C (2007) The benefits of Facebook friends Social capital and college students use of online social network sites. Journal of Computer Mediated Communication 12: 1143-1168.

7. Lemma A, Fonagy P (2013) Feasibility Study of a Psychodynamic Online Group Intervention for Depression. Psychoanalytic Psychology 30(3): 367-380.

8. Diener E, Emmons RA, Larsen RJ, Griffin S (1985) The satisfactions with life scale. Journal of Personality Assessment 49: 71-75.

9. Nielsen, Jakob (2011) How Long Do Users Stay On Webpages Nielsen Norman Group. 